\title{
$\mathrm{SCM} 440$ および S45C の破壊じん性に及ぼす オーステナイト化温度の影響
}

石原 守* 木 村 定 彦**

\section{Effect of Austenitizing Temperature on the Fracture Toughness of SCM440 and S45C Steels}

by

\section{Mamoru IsHIHARA* and Sadahiko KIMURA**}

The effect of austenitizing temperature on the fracture toughness of machine structural steels, SCM440 and S45C was investigated. Steels were austenitized at $780^{\circ} \mathrm{C}$ or $760^{\circ} \mathrm{C}, 1050^{\circ} \mathrm{C}$ and $1200^{\circ} \mathrm{C}$ and then quenched and tempered. The elastic-plastic fracture toughness $J_{\text {Ic }}$ tests by the stretched zone method were performed to obtain the fracture toughness. Also the cross section of the stretched zone was observed to evaluate the effect of the microstructure.

The results obtained are summarized as follows.

(1) For SCM440 steel the fracture toughness decreased with increasing the austenitizing temperature, while it increased slightly for S45C steel.

(2) The decrease of the fracture toughness of SCM440 steel at high austenitizing temperature was caused by embrittlement of the grain-, martensite- and acicular ferrite $\cdot$ pearlite-boundaries.

(3) The critical stretched zone width, $S Z W_{c}$ of $\mathrm{S} 45 \mathrm{C}$ steel hardly changed because the variation of the strength of pearlite grains was very small under the present heat treatment conditions. キー・ワード：オーステナイト化温度, 破壊じえ゙性値, ストレッチ・ゾーン, 機械構造用鋼

\section{1 緒言}

鋼材のじん性を改善する手段の一つとして，高温焼 入れが採り上げられ, 近年, 多くの研究結果が報告さ れてきている.これらによると,オーステナイト化温 度が上昇すると, 結晶粒径が大きくなるにもかかわら ず，破壊じん性值が向上するといら結果が 支配的とな っているが，ほとんぞ向上しないという結果も無視で きないよらである。しかし，こうした報告のほとんど は焼入材もしくは低温焼もどし材といった高強度鋼に 関するものであり，低・中強度の機械構造用鋼に関す る報告は数少なく，オーステナイト化温度の影響も明 確にされてはいない。これは，主として熱処理の質量 効果により有効な破壞じん性值が得られないことに起 因するものと考光られる。

一方, 著者らは薄板で有効な破壊じん性值が得られ る $J_{\mathrm{I}}$ 試験法を用いて，一般機械構造用鋼にお㹁る焼 入冷却速度㧍よび燒もどし温度とじん性の関係を求め, 既飞報告している.

そこで, 本研究では, 機械構造用鋼のオーステナイ 卜化温度に着目し，ストレッチ・ゾーン法による $J_{I_{e}}$ 試験を実施して，SCM 440 和よび S45C のじん性に
及ぼすオーステナイト化温度の影響について検討した。 以下に結果を報告する。

\section{2 実 験 方 法}

供試素材は，SCM 440 (機械構造用合金鋼）および S45C（機械構造用炭素鋼）の $\phi 230 \mathrm{~mm}$ の鍛延丸棒 である. Table I にそと化学成分を示す. 素材の 0.6 $R$ 部（ただし，Rは半径）より，板厚 $20 \mathrm{~mm}$, 板幅

Table I. Chemical compositions (wt \%).

\begin{tabular}{c|c|c|c|c|c|c|c|c}
\hline Material & $\mathrm{C}$ & $\mathrm{S}$ & $\mathrm{Mn}$ & $\mathrm{P}$ & $\mathrm{S}$ & $\mathrm{Ni}$ & $\mathrm{Cr}$ & $\mathrm{Mo}$ \\
\hline SCM 440 & 0.40 & 0.27 & 0.78 & 0.012 & 0.009 & 0.03 & 1.13 & 0.15 \\
S45C & 0.48 & 0.24 & 0.73 & 0.024 & 0.018 & 0.01 & 0.14 & - \\
\hline
\end{tabular}

$85 \mathrm{~mm}$, 長さ $90 \mathrm{~mm}$ の板材を採取方位 L-R に切り 出した後，オーステナイト化温度を変えた各種の熱処 理を施した. Table II に熱処理条件および熱処理後 の機械的性質を示す．な和，各オーステナイト化温度 に和ける保持時間はすべて 1 時間とし，焼もどし後の 冷却は, SCM440 では水冷, S45C では空冷とした. 破壊じん性試験片は, JSME S 001 亿準拠した, 試験片厚さ $12.5 \mathrm{~mm}$, 試験片幅 $50 \mathrm{~mm}$ のコンパク

†原稿受理 昭和60年10月28日 Received Oct.28, 1985

* 正会員, 住友重機械工業(株)平塚研究所 平塚市夕陽ヶ丘, Sumitomo Heavy Industries, Ltd., Hiratsuka Research Laboratory, Yuhigaoka, Hiratsuka

** 住友重機械工業(株)新居浜研究所 新居浜市絜開町, Sumitomo Heavy Industries, Ltd., Niihama Research Laboratory, Sobiraki-cho, Niihama 
Table II. Heat treatments and mechanical properties.

\begin{tabular}{|c|c|c|c|c|c|c|}
\hline Material & $\begin{array}{c}\text { Series } \\
\text { No. }\end{array}$ & $\begin{array}{l}\text { Auste- } \\
\text { nitizing } \\
\text { tempe- } \\
\text { rature } \\
{ }^{\circ} \mathrm{C}\end{array}$ & $\begin{array}{l}\text { Cooling } \\
\text { method }\end{array}$ & $\begin{array}{l}\text { Tem- } \\
\text { pering } \\
\text { tempe- } \\
\text { rature } \\
{ }^{\circ} \mathrm{C}\end{array}$ & $\begin{array}{c}\sigma_{Y} \\
\mathrm{kgf} / \\
\mathrm{mm}^{2}\end{array}$ & $\begin{array}{c}\sigma_{B} \\
\mathrm{kgf} / \\
\mathrm{mm}^{2}\end{array}$ \\
\hline \multirow{6}{*}{ SCM 440} & OQ 1 & 780 & \multirow{3}{*}{ Oil quench } & \multirow{3}{*}{600} & 88 & 103 \\
\hline & OQ 2 & 1050 & & & 94 & 106 \\
\hline & OQ 3 & 1200 & & & 99 & 110 \\
\hline & $\mathrm{AC} 1$ & 780 & \multirow{3}{*}{ Air cool } & \multirow{3}{*}{600} & 67 & 85 \\
\hline & AC 2 & 1050 & & & 65 & 84 \\
\hline & $\mathrm{AC} 3$ & 1200 & & & 68 & 86 \\
\hline \multirow{6}{*}{$\mathrm{S} 45 \mathrm{C}$} & OQ 1 & 760 & \multirow{3}{*}{ Oil quench } & \multirow{3}{*}{550} & 48 & 80 \\
\hline & OQ 2 & 1050 & & & 52 & 85 \\
\hline & OQ 3 & 1200 & & & 54 & 87 \\
\hline & AC 1 & 760 & \multirow{3}{*}{ Air cool } & \multirow{3}{*}{550} & 31 & 66 \\
\hline & AC 2 & 1050 & & & 35 & 73 \\
\hline & AC 3 & 1200 & & & 38 & 75 \\
\hline
\end{tabular}

卜試験片とし，熱処理後に加工して仕上げた。電気油 圧式疲労試験機を用いて， $K_{\max } \leq 80 \mathrm{kgf} / \mathrm{mm}^{3 / 2}$ で疲 労予き裂を導入した後， $J_{\mathrm{I} c}$ 試験を実施した。試験時 の負荷速度は $1 \mathrm{~mm} / \mathrm{min}$ とし, 荷重点变位は, 機械 加工により作製したナイフェッジにりリップダージを 取り付けて測定した。 J積分の算出には次式を用いた。

$$
\begin{gathered}
J=A f\left(a_{0} / W\right) / B b_{0} \\
f\left(a_{0} / W\right)=2(1+\beta) /\left(1+\beta^{2}\right) \\
\beta=\left[\left(2 a_{0} / b_{0}\right)^{2}+2\left(2 a_{0} / b_{0}\right)+2\right]^{1 / 2}-\left(2 a_{0} / b_{0}+1\right)
\end{gathered}
$$

ここで, $A$ は荷重-荷重点変位曲線下の面積, $B$ は試 験片厚さ， $b_{0}$ はりガメント幅， $a_{0}$ は予き裂長さであ る. 試験後, 試験片を疲労破断させて破面を現出し, 走査形電子顕微鏡を用いて，ストレッチ・ゾーン幅 （以下 $S Z W$ と記す）を測定した。 観察時の傾斜角は $45^{\circ}$ とし, 板厚中心部で測定した 6 点の平均値として, $S Z W_{45}$ 。を決定した。

\section{3 実験結果および考察}

\section{$3 \cdot 1 J_{I c}$ の決定}

SCM440 で求めた $S Z W_{45^{\circ}}$ と $J$ の関係を Fig. 1 に 示す. 図中のデータはいずれもストレッチ・ゾーン前 縁にディンプル破壊が認められる限界ストレッチ・ゾ

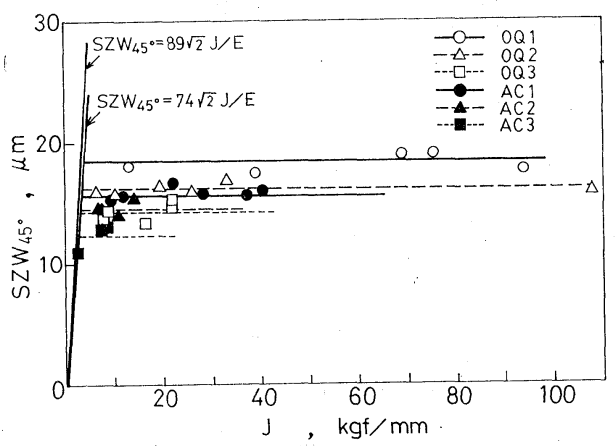

Fig. 1. SZW $W_{45^{\circ}}$ versus $J$ curves for SCM 440 .
ーンであり, 最大值はOQ1 であり, 最小值は $\mathrm{AC} 3$ と なっている. 限界ストレッチ・・゙ーン以下の実験も行 ってはいるが，数が少なく，完全な鈍化曲線は得られ なかった。そこで，前報の SCM 440 亿詨吉る鈍化曲 線より求めた次式を用いて， $J_{\mathrm{I} c}$ を計算した。

$$
S Z W_{45^{\circ}}=74 \sqrt{2} \mathrm{~J} / \mathrm{E}
$$

ここで，Eはヤング率である。な和，小林らがまとめ た鈍化曲線は図中に示したごとく， SZW $W_{45^{\circ}}=89 \sqrt{2} J / E$ となり，これで $J_{\mathrm{Ic}}$ を求めた場合, 上式の場合に比し てやや低目の值となる. $\mathrm{S} 45 \mathrm{C}$ の $S Z W_{45^{\circ}}$ と $J$ の関係 は, 前報と同様に, $S Z W_{45^{\circ}}$ と $J / \sigma_{f s}$ (ただし， $\sigma_{f s}=$ $\left.\left(\sigma_{Y}+\sigma_{B}\right) / 2\right)$ の関係に整理して Fig. 2 に示す. 本図 そ怙いても各データは限界ストレッチ・ゾーンであり,

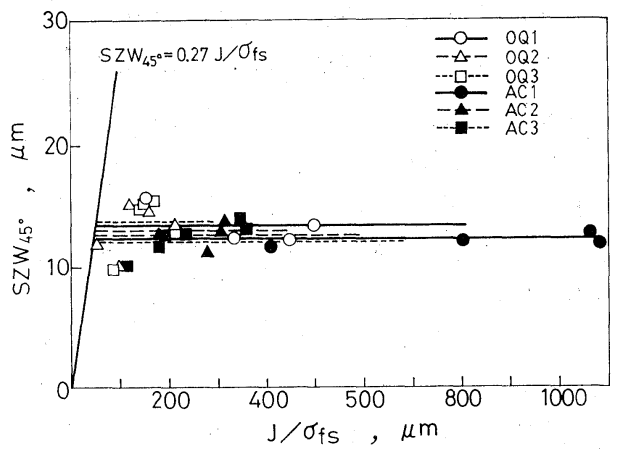

Fig. 2. $S Z W_{45^{\circ}}$ versus $J$ curves for S45C.

各シリーズごとのデータに少しばらつきが認められる が, 全体としては, SCM 440 に比して S45C はやや 低い $S Z W_{45^{\circ}}$ となって招り，比較的狭い範团内に収亦 っていた． $J_{\text {I }}$ の決定には，次式の鈍化曲線を用いた.

$$
S Z W_{45^{\circ}}=0.27 \mathrm{~J} / \sigma_{f s}
$$

以上により求めた SCM440 および $\mathrm{S} 45 \mathrm{C}$ の $J_{\mathrm{I}_{c}}$ を 一括して Table III K示す. 表中の $J_{I_{c}}$ はいずれも 次式の判定規準を満定して和り，有効な $J_{\mathrm{I}_{c}}$ すなわら 弾塑性破壞じん性 $J_{I_{c}}$ となっている.

$$
B, \quad b_{0} \geq 25 J / \sigma_{f s}
$$

Table III. $J_{I} c$ values.

\begin{tabular}{c|c|c}
\hline Material & Series No. & $J_{\mathrm{I} \boldsymbol{c}}(\mathrm{kgf} / \mathrm{mm})$ \\
\hline \multirow{5}{*}{ SCM 440 } & OQ 1 & 3.7 \\
& OQ 2 & 3.3 \\
& OQ 3 & 2.9 \\
\cline { 2 - 3 } & AC 1 & 3.2 \\
& AC 2 & 2.9 \\
S45C & AC 3 & 2.5 \\
\hline & OQ 1 & 3.2 \\
& OQ 2 & 3.3 \\
& OQ 3 & 3.5 \\
\hline & AC 1 & 2.2 \\
& AC 2 & 2.6 \\
& AC 3 & 2.6 \\
\hline
\end{tabular}




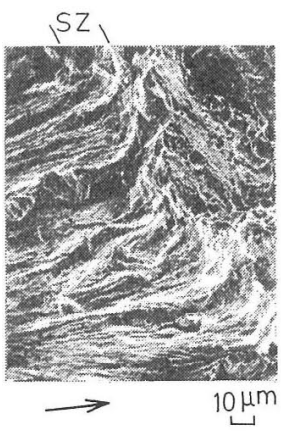

(a) $O Q 3$

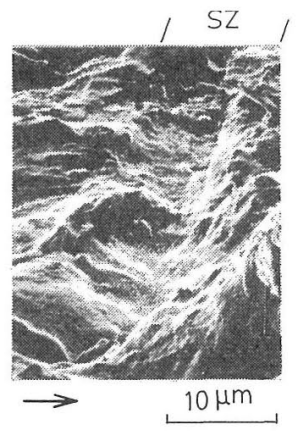

(b) $\mathrm{AC} 1$

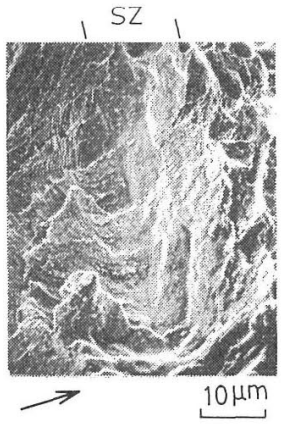

(c) $\mathrm{AC} 3$

Fig. 3. Stretched zone observed obliquely (S45C). Arrows show the crack growth direction.

$\mathrm{SCM} 440$ と $45 \mathrm{C}$ の間に $J_{\mathrm{I} c}$ の大きな差は認められ ず，いずれも $2 \sim 4 \mathrm{kgf} / \mathrm{mm}$ の範囲に入る低い值とな っている。しかし，両鋼種ともに $\mathrm{OQ}$ 材の方が $\mathrm{AC}$ 材よりも高い $J_{I_{c}}$ となって呿り，特に S45C の場合 にそれが顕著である。

な勏，以上の $S Z W_{45}$ の測定に際しては，試験片破 面のき裂伀ぱ方向と電子ビームの照射角度を種々に変 化させて確認したわけで覀るが，さらに立体的にスト レッチ・ゾーンを確認するために，き裂伝ぱ方向と直 角方向からビームを㐫て，㑯面からのストレッチ・ゾ ーン観察を試反た。結果の一部をFig. 3 に示す。いず れもき裂は左から右へと伝ぱして拈り, 左側が疲学破 面，右側がディンプル破面で㐫り，中央部がストレッ チ・ゾーンとなっている，低倍率の Fig. 3 (a)ではス トレッチ・ゾーンから证性破壞への移行状況が明りょ うであり, Fig. 3 (b)特よび(c)ではストレッチ・ゾーン

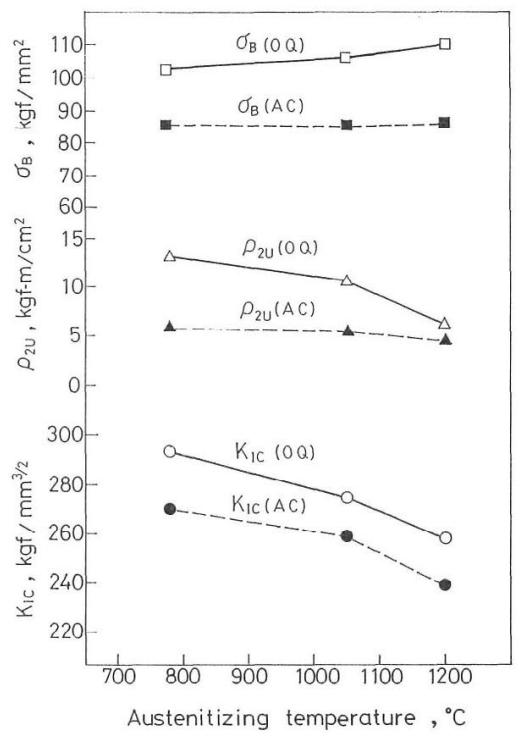

Fig. 4. Effect of austenitizing temperature on mechanical properties of SCM440.
の拡がりとSZD に相当する高さの詳細な観察が可 能となる。こうしたストレッチ・ゾーンの傾からの 観察は, ステレオ観察, マッチング写真, 破面と平行 方向からの Stretched Zone Depth の測定といった SZW の精密な測定技術の一つに挙げられ，特に SZW の小さいものの精度向上に役立つと考克られる。

\section{$3 \cdot 2$ オーステナイト化温度の影響}

オーステナイト化温度が機珹的性質に及ぼす影響を Fig. 4 护上び 5 亿示す. 図中の平面ひずみ破壊じん性 $K_{\mathrm{I} e}$ は求めた $J_{\mathrm{I}_{e}}$ 老次式で換算したものである.

$$
K_{\mathrm{I}_{c}}=\left[E J_{\mathrm{I}_{c}} /\left(1-\nu^{2}\right)\right]^{1 / 2}
$$

ここでンはポアンン比である。 SCM440 (Fig.4) では, オーステナイト化温度の上昇に伴い, $2 \mathrm{mmU}$ ノッチ シャルピー衝撃值， $\rho_{2 U}$ 招よび $K_{\mathrm{I}_{\mathrm{C}}}$ が減少するが， $\sigma_{B}$ はわずか增加する傾向が認められる。この傾向は $\mathrm{OQ}$ 材， $\mathrm{AC}$ 忉とるに同様であるが，絶対值はいずれ

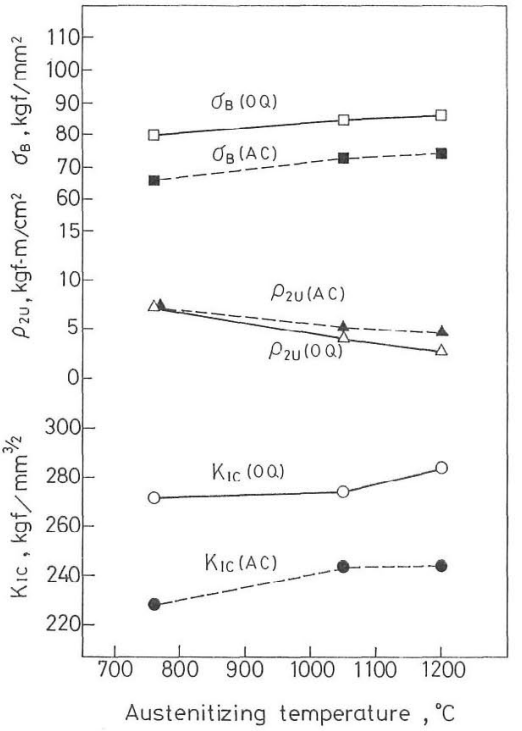

Fig. 5. Effect of austenitizing temperature on mechanical properties of S45C. 
b $\mathrm{AC}$ 材の方が低く， $K_{\mathrm{I}_{e}}$ に和ける両者の差は得ら れたオーステナイト化温度領域で湆一定となる。 $\mathrm{S} 45 \mathrm{C}$ (Fig. 5) では，オーステナイト化温度の上昇に 伴い， $\sigma_{B}$ が増加し， $\rho_{2 U}$ が減少するといら結果は SC M440 と同様であるが，K $K_{I_{c}}$ は逆にやや增加する傾向 を示す。 $\mathrm{OQ}$ 村と $\mathrm{AC}$ 材の差は $\sigma_{B}$ 特上び $K_{\mathrm{I}_{C}}$ では 明りょらであるが， $\rho_{2 U}$ ではほとんど变らない值とな る.

鋼を高温でオーステナイト化した後に暁入れすると， 破壊じえ性值が向上するといら報告では，高温焼入れ により残留オーステナイトが残り，強度の低下なしに じん性が増大するといら考光方と，高温で有害な析出 物が溶解してしまらこと学主因とする考光方がある。

一方, 破壤じえ性值は向上しないという報告では, 結晶 粒界のぜい化やマルテンサイトパケットのぜい化をと の原因として挙げている. Fig. 4 および 5 では，破懐 じえ性值の向上は大きく期待できないという結果とな って持り，特に SCM 440 ではぜい化の検討が必要に なる、そこで，限界ストレッチ・ゾーン近傍の変形状 態を断面ミク口組織で観察することとし，試験片を板 厚中心部で切断・研磨することにより，ストレッチ・ ゾーンの断面形状を確認した後, 断面をエッチングし てミクロ組織を観察した. Fig. 6 抌よび7 7 SCM440, S45C それぞれの観察例を示す。な㕲，き裂はいずれ 左から右方向へ進えでいる。 Fig. 6 (a) は SCM440 の中で最も $K_{\mathrm{I}_{e}}$ の大きい $\mathrm{OQ} 1$ の断面であり，ストレ
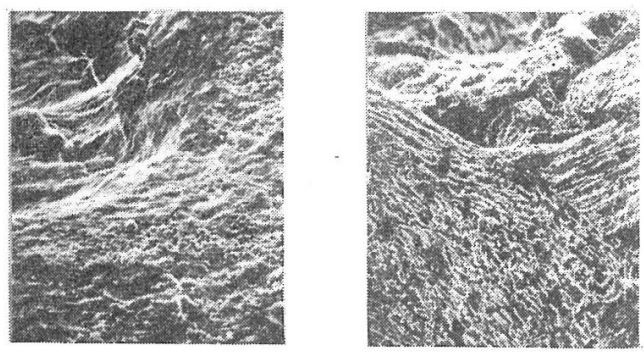

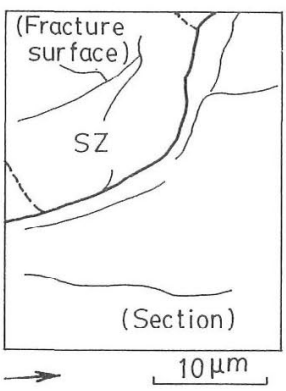

(a) $O Q 1$

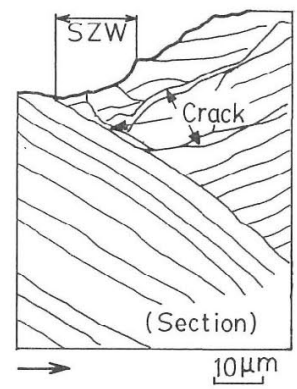

(b) $\mathrm{AC} 3$
Fig. 6. Microstructure just under stretched zone (SCM440). Arrows show the crack growth direction.
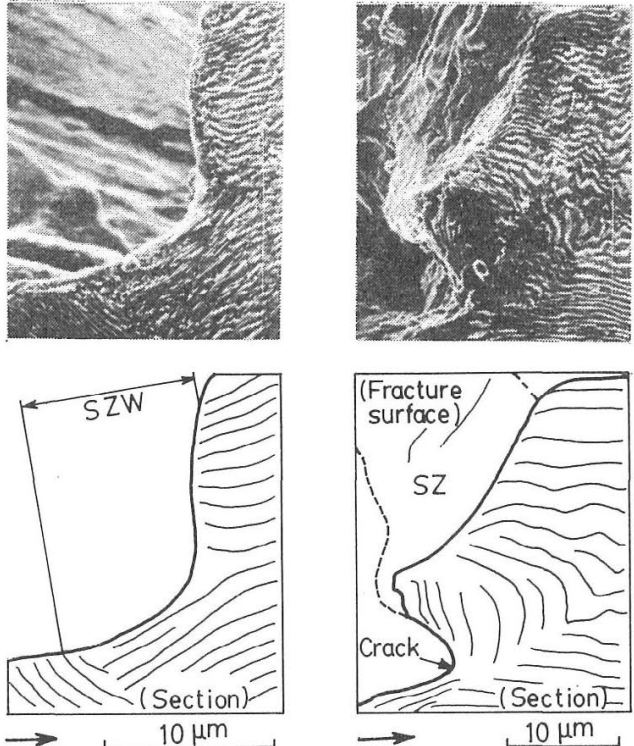

(a) OQ3

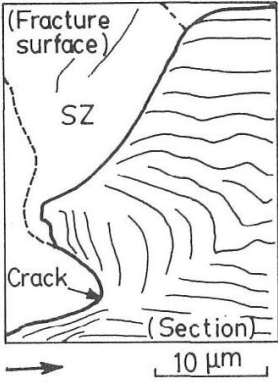

(b) $\mathrm{AC} 3$

Fig. 7. Microstructure just under stretched zone (S45C). Arrows show the crack growth direction.

ッチ・ゾーンは焼もどしマルテンサイト組織内で正常 に引き伸ばされている、しかし，最も $K_{I_{c}}$ の小さい才 ーステナイト化温度 1200 Cの AC3 に执いては, Fig. 6 (b)のごとく,ストレッチ・ゾーン直下の結晶粒界で 割孔が発生して叔り，針状フェライトとパーライトの 間の割れへと進んでいる。また，SCM 440 の場合， オーステナイト化温度 $1200^{\circ} \mathrm{C}$ OQ 3 では，ストレ ッチ・ゾーンに粒界破面が現出して招り,さらに，マ ルテンサイトパケットでの割れる認められている。し たがって，SCM440 の OQ 材拉よび AC 材の場合に, 高温でのオーステナイト化により $K_{\mathrm{I}_{c}}$ が低下していく のは，斎藤らの報告と同様に，粒界またはミク口組織 的な境界部のぜい化によるものと考光られる。F. Fig.7 (a)特よび(b)はいずれも S45C のパーライト組織内でス トレッチ・ゾーンが形成されているオーステナイト化 温度 $1200^{\circ}$ Cの S45C の OQ3 和よび AC3 の断面で 西る。Fig.7 (a)では明りょうなストレッチ・ゾーンが 形成されて和り，Fig. 7 (b)では疲労破面とストレッチ ・ゾーンの境界に割れが認められる。しかし，OQ3 とAC3 のSZW 自体には洼とえど差が無い。また， Fig. 6 (b)の割れと異なり，Fig. 7 (b)の割れは大きく開 ロして和り，近傍断面もかなり変形している。したが って，SCM440 で認められたゼい化は，S45C のオー ステナイト 化温度 $1200^{\circ} \mathrm{C}$ の材料では認められないよ

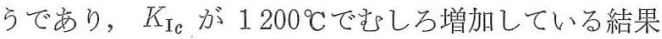
に対応していると思われる。 
Fig. 7 (b)のストレッチ・ゾーンおよび割れの形状に 関しては，武藤らの断面観察の報告におけるストレッ チ・ゾーンの割れと類似している。しかし，本実験の 範囲内では，このよらに開口量の比較的大さい割れは いずれも疲労破面とストレッチ・ゾーンの境界部で観 察されて拈り，ストレッチ・ゾーン内部での開口した 割れとは基本的に異なるようである。

\section{$3 \cdot 3$ 限界ストレッチ・ゾーン幅の検討}

オーステナイト化温度の上昇に伴い, 旧オーステナ イト粒径は大きくなる。气こで，Fig. 8 に旧オーステ ナイト粒径が限界ストレッチ・ゾーン幅, $S Z W_{e, 45}$ に 及ぼす影響を示す。 $\mathrm{SCM} 440$ では，OQ 材， $\mathrm{AC}$ 材と もに，粒径の増大に伴い $S Z W_{e, 45^{\circ}}$ が低下している。

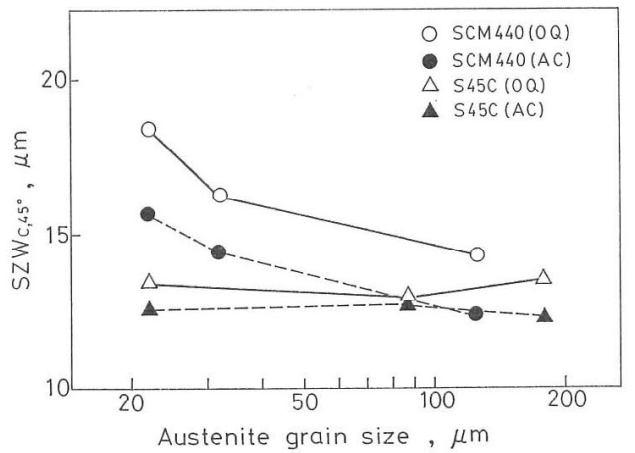

Fig. 8. Relation between critical stretched zone width, $S Z W_{c, 45^{\circ}}$ and austenite grain size.

これは，前述のごとく，オーステナイト化温度の上昇 すなわら粒径の増大により，粒界またはミク口組織的 な境界がぜい化するためであると推察される。一方， $\mathrm{S} 45 \mathrm{C}$ では，粒径が増大しても $S Z W_{c, 45^{\circ}}$ はほとんど 変化妨ず， $\mathrm{OQ}$ 材之 $\mathrm{AC}$ 材の差も小さい。この原因 を考察するために, Fig.9 に AC 材のストレッチ・ ゾーン部断面の観察例を示す。な抒，図中に物いて， き裂はいずれも左から右へと進んでいる。Fig.9(a)は 旧オーステナイト粒径が約 $22 \mu \mathrm{m}$, フェライト面積率 が約35\%のものであり，ストレッチ・ゾーン上にフェ ライトの一部电現れているが，このフェライトとパー ライトの境界では割れが発生しており，内部屯で拡が っている.Fig.9 (b)は旧オーステナイト粒径が約 180 um で，粒界にフェライトが認められるもの(フェラ イト面積率約 $6 \%$ ）であり，ストレッチ・ゾーン上の フェライトとパーライトの境界で割れが発生しておらり, 内部に桩がっている。な捇，破面上のパーライトはエ ッチングにより現出したものであるが，ストレッチン グされて拡がっている様子が断面のパーライト層との 比較で明らかとなる．Fig.9 は代表例にすぎないが，

*1 これは，粒径增大による粒界面積隇少のため，粒界での不純物濃 度か增大し，ぜい化するととに起因したあのと考えられる。
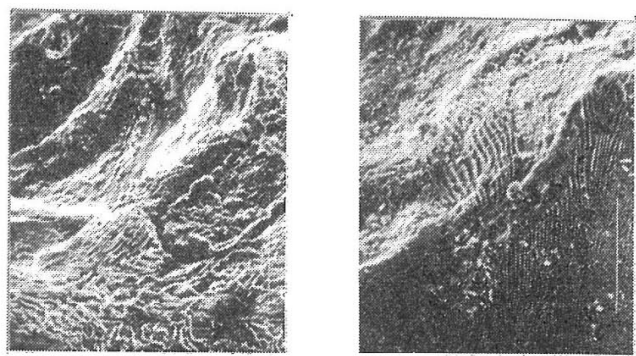

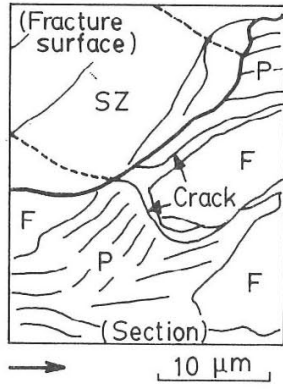

(a) $\mathrm{AC} 1$

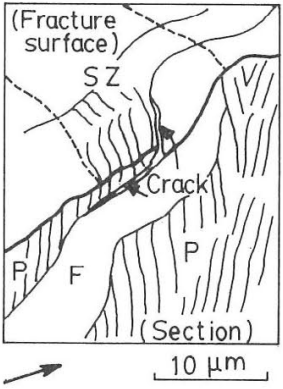

(b) AC 3
Fig. 9. Ferrite and pearlite structures just under stretched zone (S45C). Arrows show the crack growth direction.

延性の高いフェライトと強度の高いパーライトの境界 部の割れは，ストレッチ・ゾーン部で発生している割 れのほとんぞのケースで認められる。したがって，こ らしたフェライト・パーライト組織では，延性の低い パーライトの方が $S Z W_{c, 45^{\circ}}$ に対して支配的になって いると思利れる。とこで，マイクロビッカース硬度計 ですべての S45C 材のパーライトの硬度を測定した結 果，顕著な差は無く， $H_{V}$ は260～280の間に入ってい

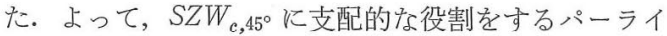
卜強度の差が小さかったことにより，Fig. 8 の S45C 各材の $S Z W_{c, 45^{\circ}}$ に明白な差が認められなかったもの と推察される。

Fig. 10 に $S Z W_{c, 45^{\circ}}$ と引張強さ， $\sigma_{B}$ の関係を示す.

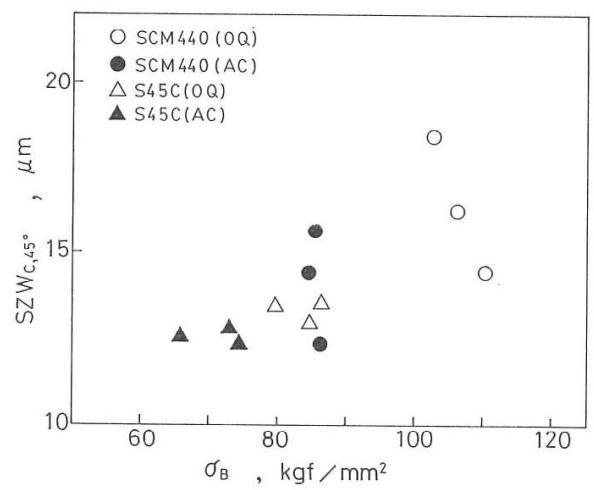

Fig. 10. Relation between critical stretched zone width, $S Z W_{c, 45^{\circ}}$ and tensile strength, $\sigma_{B}$. 
○は焼もどしマルテンサイト組織,

は針状フェライ ト・パーライト組織， $\triangle$ 㧊よびムはフェライト・パー ライト組織である。焼もどしマルテンサイト組織では, 他の組織に比して高い $\sigma_{B}$ で大きい $S Z W_{c, 45^{\circ}}$ が得ら れている.また，フェライト・パーライト組織に拈け る $\sigma_{B}$ の差は, Fig. 2 で示す鈍化曲線の傾きには影響 するが，SZW $W_{c, 45^{\circ}}$ には汇とんど影響しないと考えられ る.

$$
4 \text { 結 ‥ }
$$

SCM440 および S45C の 熱処理時のオーステナイ ト化温度が破壊じん性に及ぼす影響を検討するため,

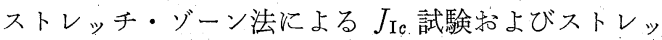
チ:ゾーンの断面観察を実施した結果, 以下の結論を 得た.

（1） SCM440の油焼入焼もどし材では，オーステナ イト化温度の上昇に伴い破壞じん性值は低減するが， S45C の油焼入焼もどし材では，わずかに増加する.

（2）オーステナイト化後に空冷して焼もどしてた材 料についても, SCM 440, S45C 各々に上記(1)と全く 同様の傾向を示す。 しかし, 破壊じん性值は油焼入焼 もどし材に比して明らかに低い值となる。

（3） SCM440の高温オーステナイト化による破壞じ え性值の低減は, 結晶粒界, マルテンサイトパケット 境界, 針状フェライトとパーライトの境界のぜい化に
起因する.

(4) S 45Cの SZW が得られた条件下で汪とんど 変化しないのは, ミクロ組織中のパーライト強度の差 が小さいことによる.

\section{参考 文 献}

1) G. Y. Lai, W.E. Wood, R. A. Clark, V. F. Zackay and E. R. Parker, Metallurgical Trans., 5, 1663(1974).

2) R. O. Ritchie and R.M. Horn, Metallurgical Trans., 9A, 331 (1978).

3）武井英雄， 中佐啓治郎，日本金属学会誌， 35， 1067 (1971).

4) 斎藤鉄哉, 内山 郁, 鉄と鋼, 61, 2038 (1975).

5) 石原 守, 篠原卓二, 石田茂樹, 杉本威生, 材料, $\mathbf{3 2}$, 366 (1983).

6) H. Kobayashi, K. Hirano, H. Nakamura and H. Nakazawa, Proc. 4 th Int. Conf. on Fracture, 3, 583 (1977).

7) JSME S001, 日本機械学会基準 (1981).

8) H. Kobayashi, H. Nakamura and H. Nakazawa, Proc. $3 \mathrm{rd}$ Int. Conf. on Mechanical Behavior of Materials, 3, 529 (1979).

9）大塚昭夫, 宮田隆司, 西村誠二, 笠井 登, 日本造船学 会論文集，139，265（1976）.

10) 武藤睦治, 坂本 勲, 関根 守, 材料, 33, 1160(1984). 